рушая ее саму. Именно поэтому в процессе конструирования традиции прежде всего принимается во внимание то, что созвучно современности, актуализируется ею и соответствует поставленным политическим иелям, а "забывается" то, что препятствует их достижению. В данном контексте важное значение приобретает понятие коммеморации, которое выступает как действенный инструмент формирования коллективной идентичности и средство консервации исторической памяти.

Ключевые слова: идентичность, коллективная память, историческая память, коммеморация, консолидация, традиция, культура.

N. Y. Kryvda, Doctor of Philosophical Science, Professor

Taras Shevchenko National University of Kyiv

60, Volodymyrska Street, Kyiv, 01033, Ukraine

\title{
CONSTRUCTING THE UKRAINIAN IDENTITY: THE CHALLENGES OF COMMEMORATION
}

The article deals with the cultural and philosophical analysis of national identity concept in the context of the "tradition invention". During the formation of collective identity, there is a reason to believe that the "invention" of the corresponding time of tradition is one of the main ways of overcoming stereotypes and practices that are considered obsolete and do not correspond to the functions assigned to them - society consolidation. Ideas, symbols and "places of memory", that receive new meaningful content, contribute to the destruction of those social models that were supported by the old tradition, destroying it itself. In this context, the notion of commemoration becomes important, which appears an effective tool for the formation of a collective identity and a means of preserving historical memory.

The main goal of the article is to identify the fundamentals of national identity in its close relationship with tradition and informal memory, as well as to formulate the notion of commemoration as an effective instrument for the formation of collective identity.

Futhermore, alongside with the need for a civilization definition, an important role in the process of "inventing the tradition" and the design of collective memory is widely declared as a desire to "break up" with the Soviet totalitarian past. The Soviet legacy is deeply rooted in Ukrainian socio-cultural and political life, and the inherent manipulative strategies, values and practices are an effective means of competition of political elites in the struggle for their own capital. The mechanical return to the intellectual constructs of the pre-Soviet period is not in last place, since they were based on "objective signs" of ethnic identification, which, in a multi-ethnic Ukrainian society, lacked sufficient symbolic capital to consolidate society.

The analyzed researches testify to the fact that taking rejection of ethnic or communist myths should be accompanied by the creation of a constructive program of the Ukrainian future.

Key words: identity, collective memory, historical memory, commemoration, consolidation, tradition, culture.

УДК 130.2:39

В. А. Личковах, д-р філос. наук, проф. Національна академія керівних кадрів культури і мистецтв, вул. Лаврська, 9, м. Київ, 01015, Україна Volodymyr.lychkovakh@ukr.net, fatv@ukr.net

\section{ФІЛОСОФІЯ ЕТНОКУЛЬТУРИ - ЕТНОКУЛЬТУРОЛОГІЯ - ЕТНОКУЛЬТУРОГРАФІЯ}

У статті досліджується взаємозв'язок філософії етнокультури, етнокультурологї та етнокультурографії як складових сучасного культурологічного дискурсу. Мета статmі - розширити уявлення про структуру сучасного культурологічного знання, зокрема через аналіз співвідношення філософії етнокультури, етнокультурології, етнокультурографії. У зв'язку з цим важливим завданням є обґрунтування поняття етнокультурографії як науково-мистецького дискурсу, в якому в образно-художній формі репрезентуються ідеї, архетипи, сигнатури, цінності етнокультури. Розкривається методологічне значення філософії етнокультури для побудови концептуальних парадигм і понятійно-категоріального інструментарію етнокультурології та культурологічної регіоніки. Вперше у сучасних науках про культуру вводиться поняття етнокультурографії як репрезентації етнокультури в художніх образах літератури і мистецтва. Зокрема, етнографічний підхід до художньої творчості аналізується на прикладах малярства відомих українських художників А. Фурлета і О. Петрової.

Ключові слова: філософія етнокультури, етнокультурологія, етнокультурографія, репрезентація етнокультури, художній образ, сигнатура, архетип, Ольга Петрова, Анатолій Фурлет.

Постановка проблеми. Сучасна культурологія вже традиційно включає до себе чотири усталених компоненти: історію культури, теорію культури, практичну культурологію та культурологічну регіоніку (регіональну культурологію) [див., напр., 2]. Крім того, розрізнюють "фундаментальну" й "прикладну" культурологію. Методологічно ця теоретична структура базується на фрілософії культури, яка $€$ різновидом модерного фрілософського знання і межує з антропологією, соціологією, етикою, естетикою. На перетині цих наук існують культурантропологія, соціологія культури, теорії морального та естетичного виховання. У своїй інтегративній єдності вони складають важливий сегмент корпусу фрілософрько-культурологічних дисциплін, які $\epsilon$ основою сучасної гуманітаристики, розкриваючи гуманістичний сенс наук про людину, суспільство, культуру.

У зв'язку із впливом глобалізаційних процесів на альтернативне поглиблення етнонаціональних ідентифікацій, зокрема на пошуки етнокультурної тотожності націй, актуалізується теоретичний інтерес до етнічної, регіональної, локальної специфіки культур окремих народів, народностей, національних меншин. З'являється етнокультурологія - наука про культурні цінності етносів, суперетносів і субетносів, про становлення і розвиток національних моделей осмислення культури, геокультурних вимірів духовного життя нації. Аналогічні процеси відбуваються і в інших напрямках гуманітарного знання: К.-О. Апель зіставляє "універсалістську макроетику" й "етноетику" [1], активно розвиваються етнологія, етнографія, етнопсихологія, етноестетика тощо. Етнокульту- рологія інтегрує всі ці знання про особливості менталітетів, соціокультурного буття і свідомості націй, етносів, субетнічних груп і культурних регіонів.

Як і кожна наука, етнокультурологія має спиратися на певні принципи організації наукового знання, розкриваючи свої теоретичні змісти через систему специфічних концептів, категорій і понять. Звісно, методологічний базис і категоріальний апарат етнокультурології багато в чому $€$ спільним 3 теоретичним оснащенням фрілософії культури, але має і власні специфрікації провідних ідей, що окреслюють предметне поле і стрижневі змісти наукового аналізу етнонаціональних культур.

У цьому сенсі найвищим шаром методологічного фундаменту етнокультурології $€$ фрілософрія етнокультури система теоретичних знань, в якій осмислюються загальні закономірності виникнення, сутності й функціонування культурних цінностей окремих етнонаціональних спільнот і регіонів. Від етнокультурології вона відрізняється більш глибокою рефрлексивністю філософрського аналізу "духовної метафізики" культури, її етноментальних характеристик, геокультурних, в т.ч. регіональних, хронотопів. У предмет фрілософрії етнокультури входить "духовна географія" краю (Фосильйон), тобто його культурний "ландшафт", що складається з неповторної єдності географічних, етнографічних, соціально-психологічних і ментальносвітоглядних вимірів життя певних етнічних спільнот.

Аналіз досліджень і публікацій. Саме такий підхід до аналізу національних культур закладений у праці Г. Гачева "Національні образи світу" [3]. Відомий росій- 
ський дослідник розрізнює особливості світосприйняття та світовідношення окремих націй на основі геокультурних і ментально-психологічних детермінант їх повсякденного та історичного життя: характеру місцевості, клімату, звичних способів руху, переживання простору i часу, міфрологічних архетипів, світоглядних і художньообразних символів. Національний образ світу виступає як ментально-естетичний інтегратор природного, соціального і духовного життя людських спільнот на окремих територіях, а тому і як фрундаментальна категорія фрілософії етнокультури.

Культурно-історичні екзистенціали людського родового буття позначаються на самоусвідомленні етносу, на конституюванні етноментальності. До речі, саме в етнічному самоусвідомленні, в неповторних стереотипах поведінки сучасні дослідники вбачають найбільш суттєву ознаку етносу, критерій етноспецифікації [див. 17]. Акад. Ю. В. Бромлей підкреслював, що етнос - це не окремий компонент культури, а певна цілісність. На нашу думку, це біосоціальна цілісність, що формується як природою, так і історією, як кревно-генетичними, так і ментальнопсихологічними характеристиками. Ще Л. М. Гумильов вважав, що етнос - це "явище природи", форма адаптації до середовища. Етногенез він пов'язував з т. зв. "пасіонарністю" - абсорбацією космічної та біологічної енергії, що створює активну спільноту, яка протиставляє себе іншим [див. 4]. До цього додаються відчуття комплементарності ("Ми", що є оппозицією "Вони") і стереотипи поведінки, які й фріксуються у спільній етноментальності.

Філософрія етнокультури звертається, відтак, до теоретичних досліджень етнокультурної ментальності народів. Останнім часом в Україні активізувалися наукові розвідки проблем теорії ментальності [див., напр., 13], в т. ч. і вітчизняної етноментальності. Сучасні українські фрілософи і культурологи звертаються до аналізу логічних передумов дослідження явища ментальності (Я. Кохан), логіко-онтологічних підстав фрагментарних пізнавальних практик у модерному вітчизняному менталітеті (О. Маєвський), сутності української етноментальності (М. Попович), її архетипів та універсалій (С. Кримський), культурно-історичних витоків (Ю. Писаренко), проблем духовності народу в українській історіософрії XIX ст. та соціальної фрілософії кінця XIX - поч. XX (Л. Депенчук). Нами розкрито методологічне значення категорій "світовідношення" та "ментальність" для аналізу слов'янських етнокультур [див. 8], введено екзистенціали "Дому", "Поля", "Храму" для побудови сіверянської культурологічної регіоніки "під сигнатурою Спаса" [6].

Мета статті - розширити уявлення про структуру сучасного культурологічного знання, зокрема через аналіз співвідношення філософії етнокультури, етнокультурології, етнокультурографії. У зв'язку з цим важливим завданням $€$ обґрунтування поняття етнокультурографії як науково-мистецького дискурсу, в якому в образнохудожній формі репрезентуються ідеї, архетипи, сигнатури, цінності етнокультури.

Виклад основного матеріалу дослідження. Наскрізним принципом філософрського осмислення етнокультурних специфікацій є теоретична кореляція загальнолюдського, етнонаціонального та регіонального в культурних змістах і формах, що побутують на різних духовних територіях. Як би не різнилися етнокультурні цінності, всім їм притаманне певне співвідношення універсального і партикулярного, спільного і специфрічного в їхніх інваріантах і вартісних смислах. Тому справжні цінності етнокультури, з одного боку, "відкриті" всьому людству як носії загальноприйнятих гуманістичних ідей, а з іншого - $є$ вичерпно "доступними", адекватно зрозумілими виключно носіям відповідної етнокультурної ментальності. "Мова" культури, відтак, має як універсальний, так і національний дискурси і справджується, як відомо, через їхній діалог, міжкультурні комунікації, духовне порозуміння.

Іея універсалізму в культурі (Я. Кучинський) якраз і ґрунтується на принципах діалогу, комплементарності, толерантності. Будь-яка етнонаціональна культура є "частиною" світової культури, більш за те, стає власне "культурою" в універсалістичному сенсі слова, коли "втягується" в орбіту загальнолюдських цінностей. Універсалізм як світогляд "єдності розмаїтого" визнає рівні права всіх етнокультур, утверджує їхню рівноцінність через діалог (полілог) в рамках глобального культурного простору. Крім того, в кожній етнокультурі $€$ момент універсалістичного, пов'язаний з її людським, гуманним, духовним значенням [див., напр., 14]. Етнічні особливості культури так чи так лише специфікують загальну ідею людини як родової істоти, надають їй особливого виявлення і неповторного забарвлення. Культура $є$ суто людським способом буття і тому вирізняє людей з природи, об'єднуючи їх у цілісний біосоціальний і духовний організм - людство. Які б етнонаціональні форми вона не приймала, її глибинна, універсалістична суть залишається незмінною - бути горизонтом людського у світі, виробляти й утверджувати родові цінності соціального буття у предметних, комунікативних чи духовних іпостасях. Це і складає основний зміст універсалістичного моменту етнокультури як культури етносу, що належить до людства в цілому і репрезентує ідею людини в певних геокультурних вимірах і традиціях.

Етнічний зміст (і форма) культури визначається природними, історичними, ментально-психологічними, мовними, світоглядними чинниками. Про вплив "географрії" (ландшафтт, характеру місцевості, клімату, навіть "рози вітрів") вже говорилося вище. Звичайно, не можна перебільшувати значення "географічного детермінізму" в розумінні етнокультури, але природне середовище і справді $€$ тим джерелом культурогенезу, яке обумовлює способи трудової діяльності, побуту, види житла, одягу і харчування. А вплив довкілля на розвиток художньої творчості та інших форм духовної культури блискуче розкрив Іпполіт Тен у своїй фрілософії мистецтва.

І дійсно, природні умови соціального буття формують специфіку національного світовідношення (образу світу), викликаючи особливості переживання простору і часу, етнокультурного хронотопу. Так, слов'янське світовідношення з цієї точки зору конституюється рівнинними, степовими, часто безкраїми краєвидами, котрі викликають своєрідний "простір" душі, відкритість, щирість, щедрість національного характеру. Яке відчуття простору і безмежних сил природи відчувається, наприклад, у народних піснях про величні слов'янські ріки Волгу, Дніпро, Дунай! А як співають українці про широкий степ і високе зоряне небо, бажаючи стати "соколом", щоб вільно літати над неосяжними просторами рідної землі! Український Sacrum спирається на ідею світовідношення як СВЯТОвідношення, що позначається на кроскультурних горизонтах фрілософії української етнокультури [9].

Не дивно, що і М. Гайдеґґер у побудові "життєвого світу" людини виокремлює позиції Землі і Неба [див. 16]. Розуміючи буття як присутність у часі, а час як "перед-просторову місцевість", німецький фрілософ усталює буттєву вкоріненість людини в рідні краєвиди, у "труди і дні" на своєму обійсті, серед землі і неба, що є вічними і часовими, сакральними і буденними горизонтами людського існування. Мислячій людині треба міркувати перш за все про найближче: про те, що стосується кожного з нас - тут і зараз, тут, на цьому клаптику рідної землі, зараз - у теперішній час світової історії. 3 цієї точки зору будь-яке справжнє творіння коріниться у ґрунті своєї рідної землі. Для підтвердження Гайдеґґер 
цитує поета Йогана Гебела: "Ми рослини, які - чи хочемо ми усвідомити це чи ні - повинні корінитися у землі, щоб, підвівшись, квітнути в етері й приносити плоди" [цит. за 10, с. 105]. І Гайдеґґер пояснює: етер тут позначає вільне повітря небес, відкрите царство духу.

Але у нього виникає питання: чи досі людина тихо мешкає поміж небом і землею? Чи є ще батьківщина, у ґрунті якої - корені людини, адже витвір мистецтва визріває на ґрунті своєї вітчизни. Відповідь Гайдеґера доволі сумна: під загрозою знаходиться сама вкоріненість сьогоднішньої людини, а втрата вкоріненості виходить із самого духу часу. Засоби масової інформації "вже сьогодні ближче людині, ніж пашні навколо його двору, ніж небо над землею, ближче, ніж зміна ночі днем, ніж звичаї та норови його села, ніж перекази його рідного світу" [16, с. 106].

Відтак, у "життєвому світі" людини, поміж Землею і Небом, Гайдеґер розміщує екзистенціали Дому, Поля, Храму. Це топоси дійсного буття людини, що визначають горизонти її вкоріненості, "Край" її особистого і родового, етнонаціонального існування. Через це вони стають і концептами - категоріями філософії етнокультури. "Дім" позначає не лише обійстя, а місце родової, родинної вкоріненості, місце зустрічі поколінь, домівку етнічного духу. "Поле" - це не просто довкілля, природне середовище, а "поле життя", той "рідний світ", в якому розгортається екзистенція людини у часопросторі природи. "Храм" - це топос Sacrum'y, місце зберігання духовних цінностей, присутність Неба на Землі. Кожна людина і кожний етнос повинні мати свій неповторний Дім, Поле, Храм, на чому ґрунтується і в чому реалізується будь-яка етнокультура.

Отже, фрілософія етнокультури як новітній напрямок народознавства безпосередньо корелює з етнокультурологією та культурологічною регіонікою, складаючи їх методологічне підґрунтя. На основі аналізу діалектики універсалістичного, етнонаціонального та регіонального в культурі вибудовуються основні принципи та категорії фрілософії етнокультури. Серед них - національний образ світу, Sacrum, "життєвий світ", хронотоп, етноментальність, універсалія, архетип, сигнатура. Зокрема, українська етноментальність спирається на такі архетипні принципи, як кордоцентризм, софрійність, антеїзм, соборність тощо. Репрезентативними для неї $€$ сигнатури Coфiї, Спаса, Богородиці, які виявляються в мистецтві та архітектурі. Важливою для конституювання фрілософрії етнокультури є і "культурологія регіону", яка розкриває загальнонаціональні універсалії з їх специфрікаціями на субетнічному рівні, у межах певного краю. Філософрія етнокультури очікує подальшого розвитку в означених перспективах.

Філософрію етнокультури й етнокультурологію збагачує етнокультурографрія - синтез наукової й мистецької рефлексії, що поєднує знання фрілософії етнокультур з їх образотворчим відтворенням художньо-естетичними засобами. Зокрема, етнокультурографрія в малярстві вимагає особливого типу дискурсу, де метафізика, естетика, семіотика, хронотопіка регіону перехрещуються з художнім баченням, індивідуальною арт-практикою митця. У цій ситуації "духовна географрія" краю (Фосильйон), його культурний "ландшафт" втілюються у візуальних образах, естетично переживаються через "графію" малярського мистецтва, тобто живописно, у симфонії кольорів. Етнокультурографрія тут набуває наочного, художньо-візуального характеру, але виконує не ілюстративну функцію, а стає самостійним методом етнокультурологічного дослідження. Митець фрактично перетворюється в дослідника, підтверджуючи пророчі слова Леонардо да Вінчі, що живопис - то найвища наука, і сполучаючи, подібно до нього, теоретичні й художні методи, наукові й мистецькі дискурси в єдине ціле. Філософія етнокультури як новітній напрямок народознавства [див. 10] збагачується, відтак, мистецтвознавчими рефлексіями [див. 11], образами мистецтва як "дзеркала" і "задзеркалля" [див. 7] географрії, етноментальності, культурної історії й духовності окремих народів.

Для митця-етнокультуролога чи не найважливішим у такій художньо-дослідницькій діяльності є знання і переживання етнохронотопів, з яких вибудовується загальна картина національного "Космо-Психо-Логосу" (Г. Гачев). Тонке відчуття особливостей часу і простору "інших берегів", занурення в глибини екзистенції, закоріненості нації в свою Землю і Небо вимагають естетичної транспозиції митця-дослідника, його "перенесення" в нові для нього плани етнонаціональної культури. Тут на допомогу приходять численні гомології в синхронії та діахронії культур, їхній "діалог", а головне - етнокультурна інтуїція митця, його здатність "Чуже" переживати як "Своє", толерантно бути не лише мислячою, а й чуттєвою "очеретиною" (Б. Паскаль). Онтологічною, геокультурною й естетичною основою такої здатності $\epsilon$ входження в хронотопи етнокультури, культурологічна й мистецька герменевтика архетипів, імен, універсалій і сигнатур національного життя, їх розуміння й відтворення в живописних образах світовідношення.

Розглянемо особливості етнокультурографії як різновиду культурологічного дискурсу на прикладі творчості київського художника Анатолія Фурлета, який звертається до репрезентацій етнокультури у своїх живописних образах, зокрема у циклі картин "Кам'яна могила". Ми вже писали про А. Фурлета як "реставратора астрального світу" [10], маючи на увазі його малярський вихід в енергоінформаційний простір духовності, в семіотику метафізичного буття. Наразі йдеться про художню реставрацію містичного світу предків, пов'язаного з "Кам'яною могилою" як "порталом" неземних хронотопів, де віддавна й до сьогодні зберігається енергетика таємничих зв'язків із Космосом. До того ж А. Фурлет дещо переінакшує ці розповсюджені уявлення про космологічну суть "Священного пагорба" під Мелітополем, акцентуючи його земне цивілізаційне значення як однієї із перших сторінок вселюдської історії, тим паче на теренах сучасної України.

\section{КАМ'ЯНА МОГИЛА}

Коди культури тут зародились, Аратта першу державу дала,

Може, портали космічні відкрились, Яв артанійський де перебува.

Нав міфотворчий тут теж розігрався, А Прав небесний і досі шука

Матір Природи, земну Magna-Mater, Оріїв-аріїв що окриля.

Графіті перші як ті піктограми

Иєрархічний порядок печер

Ладно тримають подальш від вандалів,

Акведук Духа наповнюють вщерть...

Цей культуротворчий дух "Кам'яної могили" реставрується художником у графічних і живописних роботах, навіяних древніми "чурингами", що пробуджують "бажання творити". Не тільки закодовані петрогліфи, а вся кольорова гамма посередницького (між Землею і Небом) життя і ритуалів відтворюються на його ірреальних, як завжди, мозаїчно-мерехтливих полотнах. При тому виникає враження, що ми сприймаємо не всі кольори, які бачить художник, і що за межами нашої перцепції й фурлетівських образів існують ще й інші кольори Всесвіту, не кажучи вже про барви інших галактичних вимірів. А чи бачили їх наші далекі предки? ("Ритуал 13 чуринга"). 
У зв'язку з цим закрадається підозра, що у деяких полотнах митця відображене не звичне для нас земне споглядання сучасників (від автора до тих, хто сприймає мистецтво), а те, як бачили світ автохтони "Кам'яної могили". Враження це підсилюється не тільки незрозумілими й навіть "чужими" для нас кольоровими сполученнями і раптовими акордами "диких" фрарб, а й знаками і символами на їхньому вулканічному тлі, яке вивергається з глибин земної історії й космічної позачасовості ("Край синього неба").

$€$ і замальовки первісного життя, яким воно було у гармонійному єднанні з природою, Сонцем і зірками. У бажанні наблизити весну степові номади влаштовують весняні ритуали, урочисто зустрічають золотий ранок і спекотний полудень, слухають голос трави і йдуть "до Колаксая". Любов'ю до живого, до квітів, тварин і людей просякнуті полотна "Моя квітко", "Рожевий звір", "Моя ти золота" та й практично всі інші. Висновок: давня цивілізація "Кам'яної могили" була не тільки космічною, а й екологічною та гуманістичною (чого бракує зараз!).

Зв'язок між часами, цивілізаціями, Землею і Космосом намагається налагодити сам художник. В автобіографрічному творі "Ультрамариновий перевізник" він обігрує відомий міфологічний сюжет про зв'язківця поміж світами. Його "Харон" і човен під сакральними вітрилами чомусь нагадують астронавта біля космічного корабля, а загадкова постать на передньому плані схожа на одягненого у скафандр чи то землянина, чи то інопланетянина із давньою символікою Сонця. А може, це сам митець, що теж виступає у ролі "перевізника"? Картина світла, життєдайна, оптимістична, а ультрамарин дає надію, бо символічно сполучає в собі мудрість і свободу. Подібної колористики "індиго" все більше 3'являється в нових роботах А. Фурлета [див. 15].

Ідея перевізництва посилюється сутнісно притаманною митцеві манерою творення багатошаровості образу. I у графріці, і в живописних роботах немов паралельно співіснують різні світи, хронотопи, земні й небесні виміри. I майже всюди їх простромлює якась вертикаль - людської постаті, древа життя, квітки, піраміди, трикутника, шнурового орнаменту тощо. Виникає враження руху-крізь-простір, осьової лінії часу, на яку нанизуються космічні просторища і часові еони, творячи події вічного життя як "спів-буття буття". Може, саме цей ментально-естетичний рух "нанизування" багатошаровості зображення і перетворює фрактуру і колористику фурлетівських картин у своєрідне "намисто", що мережливо-калейдоскопічно складається з розмаїтих фрагментів буття, вражень, спогадів, мрій. А ще з'являється відчуття, що все побачене художником і нами на його картинах це те, що супроводжує його на шляху "від тернин до зірок" як Перевізника, що сполучає світи і часи, душі та долі.

"Кам'яна могила" явилася Фурлету як портал міжчасових і міжпросторових переміщень, трансформацій, трансферів. У "колодязях часу" і "тунелях перельоту" митець поєднує в одне віртуальне ціле найдавнішу історію праукраїнської Аратти з ії космогенезом та етнокультурографрією. "Кам'яна могила" - це найдавніше в світі джерело писемності. Як свідчить польський санскритолог М. Красуський, ще в V-IV тис. до Христа волхви святилища в "Кам'яній могилі" карбували написи на чурингах дошумерською i шумерською мовами. А за припущенням колишнього директора заповідника Б. Михайлова, уже тоді на Подніпров"ї склалася ціла система "латинських" і "кириличних" літер [див. 5, с. 8], які на полотнах А. Фурлета набувають вигляду рун (скандинавських рунічних написів) та інших древніх письмен, а також авторських стилізованих кодів-позначень. Всі вони так чи так нагадують відкриті Б. Михайловим серед петрогліфів печери "Підкова" (№ 53) піктографрічні і буквенні знаки, відомі згодом у багатьох культурах Дворіччя, Середземномор'я, Північного Причорномор'я. А там, де писемність, - там і етнокультурогенез.
Про найдавніші корені праукраїнської культури Аратти розповідають і міфологічні мотиви картин А. Фурлета з циклу "Кам'яна могила". Передусім це численні постаті "берегинь", які сакралізують простір магічних ритуалів, архетипів Світового дерева і Світового яйця, тотемних тварин і птахів, священних рослин і квітів. Функцію "перевізника" виконує і міфологічний олень, який у багатьох стародавніх народів перевозив душі померлих на "той світ" (на картині "Ранковий петрогліф" він теж ультрамаринового кольору із золотаворайдужними вкрапленнями). Відтак, малярська етнокультурографія "Кам'яної могили" має власний міфологічний Sacrum - світ святостей, де люди йдуть "до Колаксая" - вождя, жерця, пророка, а може, й "перевізника".

В етнокультурографії знаної мисткині Ольги Петрової "дух нації", представлений на виставці "Інші береги", виявляється через активну колористичну гамму, в якій вибудовуються геокультурні особливості й артефакти народів з "інших берегів". Колір тут пов'язується не стільки з безпосередніми візуальними хронотопами, скільки 3 культурними рефлексіями мисткині, "вібрацією" її душі у подорожі духовними ландшафртами. I ще одна важлива риса її творчої манери: у відтворенні географфічних та історичних особливостей своєї веселкової імперії мисткиня йде не второваним шляхом стереотипного розуміння етнокультур, а розкриває їхню автентику через естетичне переживання хронотопів, архетипів, екзистенціалів етнокультурного життя, в т. ч. геокультурних імен.

У цьому сенсі 5 "берегів" веселкової імперії Ольги Петрової (Франція, Іспанія, Україна, арабський Схід, Японія) окреслюють духовну ойкумену мисткині, світ її реальних і віртуальних подорожей у просторі й часі євразійських культур. Кожна з них отримує своє колористичне рішення, і власне кольором у, як правило, безсюжетних чи парасюжетних композиціях створюється "метафізика" етнокультури, її духовна атмосфера, відповідний емоційно-чуттєвий настрій, аура "імені".

За авторським проектом виставки, розділ "Франиія" включає до себе естетико-психологічні транссрормації готичних вітражів та пейзажів Провансу. "Гальський" темперамент підкреслюється активною колористичною гамою, де домінує червоне в найрізноманітніших модуляціях свого етноментального та індивідуально-авторського смислового наповнення. "Дух" Франції розкривається через екстатичне "горіння" соборів, світло і сяяння сонячних ландшафтів.

Розділ "Іспанія" центрується великою за розмірами червоною абстракцією з архетиповим мотивом кола-арени. Хоча мисткиня завжди намагалася показати "Іспанію без кориди", цей мотив є, скоріше, топонімічним, психологічним, етнокультурним. Не випадково він доповнюється двома полотнами "Фрески Каталонії", де ідея улюбленої народної "гри з биками" відтінюється піднесеною анагогікою іспанської душі. Авторське бачення гарячої та водночас суворої Іспанії розкривається і через образ "Пікассо на пляжі", що колористично вдало вписується в червоновохристі й сірі композиції ("Сад Гуель", "Гірський пейзаж").

Наново відкрита мисткинею "Японія" представлена на виставці умовно-символічними образами Самурая, численними пейзажами з обов'язковою архетиповою Горою, красою "великої води" з примхливими, грайливими візерунками хвиль. Все "японське" в картинах свідомо побудоване на контрастах драми та ідилії, як про то свідчить не лише історія й культурна суть Японії, а й сама мисткиня [див. 12].

Розділ "Схід-горизонталь", на противагу "західноєвропейській" колористиці, вирішений в основному у білоблакитній гамі, яка символічно доповнюється червоною композицією. Горизонтально-панорамні полотна відтворюють пустельну безкінечність, що породжує ліричний сум, тугу за вічним життям, мудрість спокійної екзистенції. Тут реальність сприймається мисткинею як деякий симулякр, 
перманентний обнадійливий міраж, що викликає умиротворено-ідилічні настрої. Знову ж таки, на відміну і від Японії, і від Іспанії, "східно-горизонтальне" утверджує себе без душевних драм і етнокультурних контрастів.

Зал "Україна" характерний сюжетною побудовою, в якій ідейний і колористичний "фігуратив" образно виявляє ціннісно найвище і наболіле ("знайоме до болю"). Мисткиня фактично репрезентує український Sacrum [див. 9] в його духовно-шляхетних та історико-драматичних іпостасях. Етноментальний, фольклорно-веселковий дух України вдало передається через народний декоративізм "Гуцульського вівтаря" (6 композицій). Трагічною альтернативою цій українській "Аркадії" виступають портрет Г. Кочура на тлі табірної вежі, портрет О. Прицака, де переосмислюється архетип "вишиванки", бо зображена вона розіп'ятою на хресті, за яким "Голгофа" з трьома теж символічними розіп'ятими постатями українців. Ці соціокультурні настрої узагальнює композиція "Де мої діти?", на якій по чорній ріллі йде чорна приземкувата жінка із свічкою, розшукуючи свою малечу, а може, і далеких нащадків. Але, незважаючи на цю чорну семантику української долі, надію дає центрований "Янгол з віолончеллю", колористично вирішений на перетинах рожево-білих променів весняного чи ранкового пробудження.

У цілому вся виставка "Інші береги" засвідчує глибоке проникнення мисткині як в особливості етноментальності різних народів, так і у власні "концепти і перцепти" (Гваттарі, Дельоз) з приводу їх художньої рефлексії.

Відтак, етнокультурограсрія у творчості Ольги Петрової доповнюється "культурографією душі", еніоестетичним просякненням у "Психо-Космо-Логос" людини. Ї̈̈ малярство виступає як мистецька репрезентація етнокультури в художніх образах, тобто як правдива етнокультурографія.

Висновок. Таким чином, саме співвідношення філософії етнокультури - етнокультурології - етнокультурографії лежить в основі аналізу мистецьких репрезентацій етнокультури, складаючи його методологічне підґрунтя. Взаємодоповнення фрілософських, культурологічних та художньо-естетичних позицій в осмисленні мистецького відтворення ЦСУ народу, його етнокультурних цінностей і традицій створює цілісну картину взаємодії світогляду, ментальності, міфопоетики і фрольклору будь-якого народу.

\section{СПИСОК ВИКОРИСТАНИХ ДЖЕРЕЛ}

1. Апель К.-О. Етноетика та універсалістська макроетика: суперечність чи доповнювальність? / К.-О. Апель // Політ. думка. - 1994. - № 45

2. Второй Российский культурологический конгресс с международным участием "Культурное многообразие: от прошлого к будущему": Программа. Тезисы докладов и сообщений. - СПБ., 2008. Науки про культури: культурологія, kulturoznawstwo, культуроведение, Cultural Studies: [колективна монографрія]. Редактор-укладач Кирилова О. О. К.: Вид-во НПУ ім. М. П. Драгоманова, 2015. - 338 с.

3. Гачев Г. Национальные образы мира / Г. Гачев. - М.: Сов. писатель. $-1988 .-233$ с.

4. Гумилев Л. Н. Этногенез и биосфера Земли / Л. Н. Гумилев. - Л., 1989. $-560 \mathrm{c}$.

5. Довгич В. Матір Індо-Європа / В. Довгич // ІндоЄвропа: Онуки Дажбожі. - Кн.1-2. - К., 1996-1997. - С.8.

6. Личковах В. А. Дивосад культури: Вибр. ст. / В. А. Личковах. Чернігів: Деснянська правда, 2006. - 159 с

7. Личковах В. А. "Зазеркалье" неклассической эстетики / В.А.Личковах, О. Н. Петрова // Перспективы метафизики: классическая и неклассическая метафизика на рубеже веков. - СПб., 1997. - С. 45-46.
8. Личковах В.А. Методологічне значення концепцій світовідношення і ментальності для дослідження духовного світу слов'янських культур / В. А. Личковах // Вісник чДПУ: Духовний світ слов'янських культур. Серія "Філос.науки". - Вип. 26. - Чернігів, 2004. - С. 9-14.

9. Личковах В. А. Український Sacrum: світовідношення як святовідношення (кроскультурні горизонти філософрії етнокультури) / В. А. Личковах // Філософрія етнокультури та морально-естетичні стратегії громадянського самовизначення. - Чернігів, ЦНТЕІ, 2006. - 180 с

10. Личковах В. А. Філософрія етнокультури: Теоретико-методологічні та естетичні аспекти історії української культури / В. А. Личковах. - К.: ПАРАПАН, 2011. - $196 \mathrm{c}$

11. Петрова О. Мистецтвознавчі рефлексії / О. Петрова. - К., Видавничий дім "КМ Академія", 2004. - 382 с.

12. Петрова О. Япония: Дневник туриста в "розовых очках" / О. Петрова. - К., б.г. (рукопись).

13. Проблеми теорії ментальності / Відп. ред. М.В.Попович. - К., Наукова думка, 2006. - 404 с.

14. Універсальні виміри української культури / НАН України. Укр. фрілос. фонд / За ред. проф. О. С. Кирилюка. - Одеса: Друк, 2000. - 216 с.

15. Фурлет А. Живопис / А. Фурлет. - К.: "Білий світ", 2016. - Б.с

16. Хайдеггер М. Разговор на проселочной дороге / М. Хайдеггер. М.: Высшая школа, 1991. - 192 с.

17. Этносы и этнические процессы. Памяти Р. Ф. Итса: Сб.ст. - М.: Восточная литература, 1993. - 356 с.

\section{REFERENCES}

1.Apel, K-O (1994) Etnoetika ta universalists'ka makroetika: superechnist' chi dopovnjuval'nist'? [Ethnoethics and Universalistic Macroethics: Contradiction or Complementarity?]. Polit.dumka, 45.

2. Vtoroj Rossijskij kul'turologicheskij kongress $s$ mezhdunarodnym uchastiem "Kul'turnoe mnogoobrazie: ot proshlogo k budushhemu": Programma (2008). [The Second Russian Cultural Congress with International Participation "Cultural Diversity: From the Past to the Future"] Tezisy dokladov i soobshhenij. SPB. In Nauki pro kul'turi: kul'turologija, kulturoznawstwo, kul'turovedenie, Cultural Studies (2015). [kolektivna monografija]. Kyiv, Vid-vo NPU im. M. P. Dragomanova.

3. Gachev, G. (1988). Nacional'nye obrazy mira [National images of the world]. Moskow, Sov.pisatel'.

4. Gumilyov, L. N. (1989). Jetnogenez i biosfera Zemli [Ethnogenesis and the Biosphere of Earth]. Leningrad.

5. Dovgich, V. (1996-1997). Matir Indo-Evropa [Mother Indo-Europe]. In Indo€vropa: Onuki Dazhbozhi, Kn.1-2. Kyiv.

6. Lychkovakh, V.A. (2006). Divosad kul'turi: Vibr.st. [Wonder-Garden of Culture: Selected Articles]. Chernigiv, Desnjans'ka pravda.

7. Lychkovakh, V. A. and Petrova, O. (1997). "Zazerkal'e" neklassicheskoj jestetiki ["Through the Looking Glass" of non-classical aesthetics]. In Perspektivy metafiziki: klassicheskaja i neklassicheskaja metafizika na rubezhe vekov. SPb.

8. Lychkovakh, V. A. (2004). Metodologichne znachennja koncepcij svitovidnoshennja i mental'nosti dlja doslidzhennja duhovnogo svitu slov'jans'kih kul'tur. [The methodological significance of the concepts of world attitude and mentality for the study of the spiritual world of the Slavic cultures]. Visnik ChDPU: Duhovnij svit slov'jans'kih kul'tur. Serija "Filos.nauki", 26, 9-14.

9. Lychkovakh, V. A. (2006). Ukraïns'kij Sacrum: svitovidnoshennja jak svjatovidnoshennja (kroskul'turni gorizonti filosofiï etnokul'turi). [Ukrainian Sacrum: world-relation as a holy-relation (crosscultural horizons of the philosophy of ethnoculture)]. In Filosofija etnokul'turi ta moral'no-estetichni strategiï gromadjans'kogo samoviznachennja. Chernigiv, CNTEI.

10. Lychkovakh, V. A. (2011). Filosofija etnokul'turi: Teoretikometodologichni ta estetichni aspekti istoriï ukraïns'koï kul'turi. [Philosophy of Ethnoculture: Theoretical-Methodological and Aesthetic Aspects of the History of Ukrainian Culture]. Kyiv, PARAPAN.

11. Petrova, O. (2004). Mistectvoznavchi refleksiï [Art studies reflections]. Kyiv, Vidavnichij dim "KM Akademija".

12. Petrova, O. Japonija: Dnevnik turista v "rozovyh ochkah" [Japan: Diary of a tourist in "pink glasses"]. Kyiv, b.g. (rukopis').

13. Problemi teorii mental'nosti [Problems of the theory of mentality] (2006). Kyiv, Naukova dumka.

14. Universal'ni vimiri ukraïns'koï kul'turi [Universal measurements of the Ukrainian culture] (2000). Odesa, Druk.

15. Furlet, A. (2016). Zhivopis [Painting]. Kyiv, Bilij svit.

16. Heidegger, M.(1991). Razgovor na proselochnoj doroge [Country Path Conversations]. Moskow, Vysshaja shkola.

17. Jetnosy $i$ jetnicheskie processy [Ethnoses and ethnic processes] (1993). Pamjati R. F. Itsa: Sb. st. Moskow, Vostochnaja literatura.

Надійшла до редколегії 29.08.17

В. А. Личковах, д-р филос. наук, проф.

Национальная академия руководящих кадров культуры и искусств,

ул. Лаврская, 9, г. Киев, 01015, Украина

\section{ФИЛОСОФИЯ ЭТНОКУЛЬТУРЫ - ЭТНОКУЛЬТУРОЛОГИЯ - ЭТНОКУЛЬТУРОГРАФИЯ}

В статье исследуется взаимосвязь философии этнокультуры, этнокультурологии и этнокультурографии как составляющих современного культурологического дискурса. Цель статьи - расиирить представление о структуре современного культурологического знания, в частности через анализ соотношения философии этнокультуры, этнокультурологии, этнокультурографии. В связи с этим важной задачей является обоснование понятия этнокультурографии как научно-художественного дискурса, в котором в образно-художественной форме репрезентируются идеи, архетипы, сигнатуры, ценности этнокультуры. Раскрывается методологическое значение фолософии этнокультуры для построения концептуальных парадигм и понятийно-категориального инструментария этнокультурологии и культурологи- 
ческой регионики. Впервые в современных науках о культуре вводится понятие этнокультурографии как репрезентации этнокультуры в художественных образах литературы и искусства. В частности, этнографический подход к художественному творчеству анализируется на примерах живописи известных украинских художников А. Фурлета и О. Петровой.

Ключевые слова: философия этнокультуры, этнокультурология, этнокультурография, репрезентация этнокультуры, художественный образ, сигнатура, архетип, Ольга Петрова, Анатолий Фурлет.

V. A. Lychkovakh, Doctor of Philosophical Sciences, Professor,

National Academy of Managerial Staff of Culture and Arts

Lavrska str., 9, Kyiv, 01015, Ukraine

\section{PHILOSOPHY OF ETHNOCULTURE - ETHNOCULTUROLOGY - ETHNOCULTUROGRAPHY}

The article investigates interrelation between philosophy of ethnoculture, ethnoculturology and ethnoculturography as components of modern culturological discourse. Aim of the article is to extend the idea about the structure of modern culturological knowledge and, in particular, to analyze how philosophy of ethnoculture, ethnoculturology and ethnoculturography correlate with each other. In connection with this there is an important task - to ground the notion of ethno-culturalography as a discourse of science and art, in particular the discourse in which ideas, archetypes, signatures and values of ethnoculture are represented in a figuratively-artistic form. The methodological value of philosophy of ethnoculture is revealed for the construction of conceptual paradigms and conceptual tools of ethnoculturology and culturological regional studies. The concept of ethnoculturography as representation of ethnoculture in artistic images of literature and art is entered in modern sciences about the culture for the first time. In particular, ethnographic approach to artistic creativity is analyzed on the examples of painting of well known Ukrainian artists Olha Petrova and Anatolii Furlet.

The author understands ethnoculturology as synthesis of scientific artistic reflection that combines knowledge of ethnocultures with their pictorial reproduction by means of artistic and aesthetical facilities. For instance, ethnoculturography in painting requires a special type of discourse, where metaphysics, aesthetics, semiotics and chronotopes of the region are crossed with artistic vision, individual practice of the artist. In works of Anatolii Furlet it is manifested through artistic restoration of the mystic world of ancestors connected with "A Stone Grave" near Melitopol - one of the oldest monuments of world and national culture. For ethnoculturology of Olha Petrova the "spirit of nation" in its multicultural measurements was presented at the exhibition "Other Shores". Five "shores" of spiritual oecumene of the artist (France, Spain, Ukraine, Arabic East, Japan) outline ethnic horizons of her real and virtual travels in space and time of Eurasian cultures. Consequently, ethnoculturology practically becomes an original guide-book, a road sign (vade mecum) in the world of ethnocultures.

Keywords: philosophy of ethnoculture, ethnoculturology, ethnoculturography, representation of ethnoculture, artistic image, signature, archetype, Olha Petrova, Anatolii Furlet.

УдК 18:7.01

О. І. Оніщенко, д-р філософ. наук, проф. Київський національний університет театру, кіно і телебачення ім. Карпенка-Карого, вул. Ярославів вал, 40, м. Київ, 01054, Україна kafedra.eec.dep@gmail.com

\section{ПОЛЬСЬКИЙ ЕСТЕТИЧНИЙ ДИСКУРС ХХ СТ.: ІНТЕРПРЕТАЦІЯ ІНТЕРПРЕТАЦІЙ}

Стаття присвячена аналізу польського естетичного дискурсу XX cm. та перспективам його інтерпретації в українській естетиці, зокрема є роботі К. Шевчук, що захищається на кафедрі етики, естетики та культурологї Київського національного університету імені Тараса Шевченка. Ці розробки значно розширюють уявлення про канон польської естетичної думки, класично представлений іменами таких польських естетиків, як Р. Інеарден і В. Татаркевич, та відкривають імена фактично невідомих в Украйні польських науковців, серед яких особливий інтерес викликає доробок Л. Блауштайна, М. Валліса, Г. Ельзенберга та С. Оссовського. У даній перспективі висвітлюються вже традиційні для естетики XX століття проблеми, зокрема психологія художньої творчості, колективність естетичного переживання, співвідношення фантазї та уяви. Також відкриваються нові інтерпретаційні перспективи піднесеного та потворного, естетичного переживання та досвіду.

Ключові слова: інтерпретація, естетичне переживання, естетичне почуття, емоція, франтазія, потворне, експресія, стимул.

Постановка проблеми. Процеси, що відбувалися в єBропейській естетичній теорії в умовах XX ст., не тільки розширили, а й значною мірою модернізували її концептуальний спектр, визначивши нові ракурси дослідження класичних проблем, що сформували теоретичний фундамент естетичної науки. Вагомий внесок у цьому плані було здійснено яскравими репрезентантами польської естетики Р. Інгарденом (1893-1970) і В. Татаркевичем (1886-1980), що їхній доробок завжди привертав увагу українських дослідників.

Аналіз досліджень і публікацій. Осягнення засадничих концепцій Р. Інгардена і В. Татаркевича, вочевидь, мало для естетичних розвідок в Україні неабиякий "теоретичний позитив", проте водночас спричинило досить провокаційну ситуацію. Адже доробок польської естетичної школи фактично ототожнювався з визначними, однак - тільки цими двома іменами, створюючи в персоналізованому просторі української естетики ситуацію очевидного дисбалансу. Иого ліквідації, безсумнівно, посприяє докторська дисертація К. Шевчук "Аксіологічний вимір естетичного переживання в польській естетиці першої половини XX ст." (науковий керівник доктор фрілософських наук, професор В. Панченко), виконана на кафедрі етики, естетики та культурології Національного університету імені Тараса Шевченка.

Мета статті: здійснити інтерпретацію польського естетичного дискурсу XX ст. в контексті теоретичного горизонту української естетики.
Виклад основного матеріалу дослідження. Слід завважити, що дисертаційні роботи, підготовлені на цій кафедрі, вирізняє не тільки високий науковий рівень, але й оригінальність проблематики, яка спонукає, принаймні нас, до власних розмислів і пошуків. Вперше наслідком цього "теоретичного натхнення" стала стаття "Трансгресивний досвід Ж. Батая в динаміці культуротворчих процесів" ("Культурологічна думка", К., 2016), написана під впливом кандидатської дисертації $€$. Буцикіної "Концепція трансгресивного досвіду Жоржа Батая: естетичний аналіз" (науковий керівник - кандидат фрілософських наук, доцент І. Живоглядова), вдруге - дана стаття, стимульована означеною вище дисертацією К. Шевчук. Відтак, очевидним є формування своєрідної тенденції, що виявляє ознаки певного підходу, який потребує хоча б умовного визначення.

Наразі скористаємося власним прийомом, що був застосований під час написання одного з підрозділів, присвяченого епістолярію Ф. Ніцше, нашої останньої монографії "Культуротворчий потенціал епістолярію: європейський досвід другої половини XIX - першої половини XX ст." (К., 2017). Так, задля виявлення концептуальних підтекстів у певних листах німецького фрілософа нами здійснювалася не тільки власне їх розвідка, але й відбувалося звернення і до досвіду аналізу, проведеного іншими дослідниками. Отже, прийом, котрий був використаний, ми визначили як "інтерпретація інтерпретацій", фрактично перефразувавши, проте досить чітко

(c) Оніщенко О. I. 